\title{
Application of the New City-Suburban Heavy Vehicle Route (CSHVR) to Truck Emissions Characterization
}

Nigel N. Clark, James J. Daley, Ralph D. Nine and Christopher M. Atkinson

West Virginia Univ.

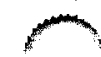

Reprinted From: Topics in General Emissions

(SP-1459)

Permission is hereby granted for a copyright release fee of $\$ 300$ per paper. An invoice will follow under separate cover. Please be sure to include the following credit statement with these papers:

"C Society of Automotive Engineers, Inc. The following papers are published on this web-site with permission from the Society of Automotive Engineers, Inc. As a user of this web-site, you are permitted to view these papers on-line, download the PDF file and to print a copy at no cost for your use only. Dowloaded PDF files and printouts of SAE papers

contained on this web-site may not be copied or distributed to others or for the use of others." 


\title{
Application of the New City-Suburban Heavy Vehicle Route (CSHVR) to Truck Emissions Characterization
}

\author{
Nigel N. Clark, James J. Daley, Ralph D. Nine and Christopher M. Atkinson \\ West Virginia Univ.
}

Copyright 1999 Society of Automotive Engineers, Inc.

\section{ABSTRACT}

Speed-time and video data were logged for tractor-trailers performing local deliveries in Akron, $\mathrm{OH}$. and Richmond, VA. in order to develop an emissions test schedule that represented real truck use. The data bank iveloped using these logging techniques was used to Ite a Yard cycle, a Freeway cycle and a City- uurban cycle by the concatenation of microtrips. The City-Suburban driving cycle was converted to a driving route, in which the truck under test would perform at maximum acceleration during certain portions of the test schedule. This new route was used to characterize the emissions of a 1982 Ford tractor with a Cummins 14 liter, $350 \mathrm{hp}$ engine and a 1998 International tractor with a Cummins 14 liter, $435 \mathrm{hp}$ engine. Emissions levels were found to be repeatable with one driver and the driver-to-driver variation of $\mathrm{NO}_{\mathrm{x}}$ was under $4 \%$, although the driver-to-driver variations of $\mathrm{CO}$ and PM were higher. Emissions levels of $\mathrm{NO}_{x}$ for the Ford tractor at a test weight of $46,400 \mathrm{lb}$. using the CSHVR were comparable with values obtained using the WWU 5 mile route and the EPA Urban Dynamometer Driving Schedule for Heavy Duty Vehicles ("Test D"). The PM emissions were slightly higher for the CSHVR than the 5 mile route and Test $D$. The effect of test weight on emissions, in units of mass/distance, was assessed using the International tractor with the CSHVR at 26,000, 36,000 and 46,400 lb. test weights. Variation of all regulated exhaust emissions was small between test weights, although the $\mathrm{CO}_{2}$ level reflected the additional energy used at higher weights. The small variation in regulated emissions may be attributed to the fact that in all three cases, the route fulled for full power operation of the vehicle, and that

PM puff associated with gear shifting would be sımilar. It is concluded that the CSHVR represents a useful and realistic test schedule for truck emissions characterization.

\section{INTRODUCTION}

Alternative fuels have been promoted as a national approach to the reduction of harmful atmospheric emissions, but in the heavy duty vehicle arena, testing methods for emissions comparison have not been well established. Although there are claims that certain species in the tailpipe are reduced, relative to diesel, when employing biodiesel $(1,2)$, FischerTropsch fuels $(3)$, alcohols $(4,5)$ and natural gas $(6)$, it is difficult to quantify the actual in-use benefits unambiguously because the test schedule used can influence the conclusions reached. For example, chassis dynamometer tests with high idle time were found to favor the engine of one manufacturer over another, relative to tests with less idle time (7). There is a need to develop a standardized test protocol for heavy duty chassis dynamometer based emissions characterization that reasonably represents vehicle behavior in actual use. Since one substantial contributor to the urban mobile source emissions inventory is the Class 7 or 8 delivery truck, these were selected as the subjects for cycle development. This paper presents some of the first emissions data using test schedules arising from the cycle development study, while the creation of these schedules has been discussed in more detail elsewhere $(8,9)$.

Reasonably representative test protocols for the comparison of the emissions performance between diesel and alternative fuel vehicles do not exist and present testing procedures use outmoded or ad hoc cycles for this purpose. For buses the Central Business District Cycle (SAE Recommended Practice J1376) has become the norm, but for truck testing there is no nationally recognized test schedule. Previously the West Virginia University (WVU) researchers have employed the 5 peak cycle (10) and the 5 mile route (11) while researchers in Colorado have employed the 5 peak cycle and the EPA Urban Dynamometer Driving 
'Schedule for Heavy Duty Vehicles (12). It is widely acknowledged that the emissions, reported in units of mass/distance, are influenced by the driving cycle used $(6,12)$ and that the cycle variation will cause different engine technologies to alter the emissions in different ways. In other words, one may reach different conclusions on the benefits of a technology based upon the cycle chosen (7).

With funding from the National Renewable Energy Laboratory, the present researchers have logged data from trucks in service to create both traditional speed vs. time cycles and routes, in which some acceleration at maximum power is required from the vehicle under test. $(9,8,13)$. This paper reports the emissions data gathered from two trucks using these new cycles.

\section{VEHICLES TESTED}

Two Class 8 heavy duty road tractors were used to evaluate the CSHVR developed previously $(8,9)$ using the Transportable Heavy Duty Vehicle Emissions Testing Laboratory (THDVETL) at WVU. A 1982 Ford L9000 road tractor, powered by an older technology 14 liter Cummins 350 horsepower engine with a PT injection system using \#2 diesel fuel, was used to verify the cycles initially on a heavy duty chassis dynamometer. Shifting the Ford L9000 tractor was accomplished through a 15 speed unsynchronized transmission (this transmission has one set of deep reduction gears and is typically used as a 10 speed). A 1998 International Eagle road tractor, powered by a Cummins 435 horsepower engine with electronic injection and using \#2 diesel fuel, was used to show - repeatability of test-to-test emissions results, to show driver-to-driver variability in emission results due to differing driver behavior patterns, and to determine the effect of changing the simulated test weight. Shifting the International Eagle tractor was accomplished through a 10 speed unsynchronized transmission.

\section{WVU CHASSIS DYNAMOMETER}

All cycle and route emissions tests were completed on the WVU THDVETL. Testing was completed while the transportable laboratory was located at its home base in Morgantown, West Virginia. This transportable laboratory was designed to evaluate the emissions from heavy duty trucks and buses, and has been used widely in the evaluation of alternative fuel technologies $(6,7,14)$. The chassis dynamometer test bed is constructed from a flat bed trailer. Setting up the chassis dynamometer is accomplished by first separating the tractor from the test bed. Next, four hydraulic lifts are used to raise the test bed so that the rear axles can be removed. Once the tractor and rear axles are removed the test bed can be lowered to the ground for chassis dynamometer use. After placing the lest bed on the ground a vehicle can be driven onto the test bed for testing. The vehicle's drive wheels are placed on two sets of 12.6 inch diameter rollers. Axle power is distributed from the vehicle to the test bed by use of two hub adapters. The hub adapters are connected directly to the drive axle of the vehicle to eliminate frictional losses on the rollers. Two Lebow torque transducers are linked to the hub adapters by driveshafts so that instantaneous axle torque measurements can be made with minimal chassis dynamometer drive train loss. Weight simulation for each heavy duty vehicle is accomplished through two sets of inertia flywheels. Wind drag and tire loss simulation is accomplished through the use of two eddy current dynamometers. The second part of the transportable laboratory is dedicated solely to emissions measurement. The vehicle's exhaust is connected to a full scale ambient air dilution tunnel. Air flow through the dilution tunnel is controlled by critical flow venturis. Exhaust samples of Hydrocarbons (HC), Carbon Dioxide $\left(\mathrm{CO}_{2}\right)$, Carbon Monoxide (CO) and Oxides of Nitrogen $\left(N O_{x}\right)$ are collected using heated probes and lines after mixing has occurred in the dilution tunnel. Particulate Matter (PM) is collected by filters located below a secondary dilution tunnel, that withdraws a slipstream from the main tunnel. A vehicle is exercised through a test schedule by a commercial driver prompted by a screen trace, or driver,s aid.

\section{CYCLE AND ROUTE DEVELOPMENT}

This section describes briefly the origin of the new cycles employed in the present research. A full account of the development of cycles used in this program has been given in references $(8,9)$.

Two heavy duty tractors were selected by the American Trucking Association (ATA) for data acquisition by West Virginia University. The on-road tractors selected were fueled by liquid natural gas (LNG) and stationed at Roadway Express, Inc. in Akron, Ohio and Overnite Inc. in Richmond, Virginia. These tractors had daily operating routes, which included 4-lane freeway travel, inner city pickups and deliveries, 2-lane suburban road driving, and industrial park pickups and deliveries. A 5.9 liter Cummins engine operating on liquid natural gas (LNG) powered the single drive axle Roadway Express, inc. tractor and shifting was accomplished through an unsynchronized 6-speed manual transmission. An 8.3 liter Cummins engine operating on LNG powered the single drive axle Overnite Transportation tractor and shifting was accomplished through a 5-speed automatic transmission.

Speed and distance data were collected on these two vehicles for a total of 49 hours. A videotape record of these tractors was also collected so that the speed and distance database could be separated into microtrips. A microtrip is defined as a burst of driving activity typically due to driving from one delivery site to another (9). The database consisted of 130 microtrips, with 77 microtrips from Roadway Express, Inc. and 53 microtrips from Overnite Transportation Co. Each microtrip was classified into one of four following driving modes: Freeway, Suburban, City and Yard. Freeway microtrips included four-lane highways with entrance and 
exit ramps. City microtrips encountered denser traffic and multiple stop lights. Suburban microtrips were delivery routes on the outskirts of the city, which -luded industrial parks and some rural areas as well. I microtrips were considered any microtrips that ... olved changing trailers, changing tires or driving to fueling sites.

Three criterion were calculated for each of the four driving modes in the database, namely average vehicle speed, standard deviation of vehicle speed, and average cruise time. Each criterion was calculated with the idle time of the vehicle removed so that each microtrip could be characterized by the vehicle's motion and not the time spent at a standstill. After all criteria for each microtrip were calculated, idle times were once again added back into the microtrip.

A Basic program was written to concatenate microtrips randomly within each driving mode. The program added together microtrips until the total time of the concatenated microtrips was between 1000 and 1600 seconds in length, to form a cycle. Then comparing statistics between the entire driving mode database and the cycle, a Root Mean Square (RMS) error value was calculated for the cycle. The three criteria were weighted evenly in calculating the RMS error Value. Then the cycle with the lowest RMS error value was selected to be the representative cycle for that particular driving mode.

Three cycles developed using this reduction procedure, namely the Yard, City-Suburban and Freeway cycles, are discussed in this paper. Properties for each of these cycles are shown in Table 2, and speed vs. time graphs for the cycles are shown in Figures 1,2 and 3 . The City-Suburban cycle was converted to the City-Suburban Heavy Vehicle Route (CSHVR) using the videotape information. If the videotape did not show that the truck was inhibited by ulterior conditions when accelerating, the acceleration was said to be "free" and should be interpreted as acceleration at the maximum rate. When the tape showed that the progress of the original vehicle was inhibited, then that acceleration ramp portion was left exactly as recorded. Free accelerations were exhibited in the test schedule and on the driver's aid by converting an acceleration ramp into an instantaneous speed jump to the desired speed (9). Since the accelerations are free, the scheduled route speed is now a function of distance traveled and not a function of time. Properties for the CSHVR are shown in Table 3 and a speed vs. distance trace is shown in Figure 4.

Table 1. Specifications on the two vehicles used for testing at WVU.

\begin{tabular}{|l|c|c|}
\hline Make and Model & Ford L9000 & International Eagle \\
\hline Year & 1982 & 1998 \\
\hline Displacement & 14 liters & 14 liters \\
\hline Rated Horsepower & 350 & 435 \\
\hline Manual Transmission & 15 -speed & 10 -speed \\
\hline
\end{tabular}

Table 2. Properties for Yard, City-Suburban and Freeway cycles.

\begin{tabular}{|c|c|c|c|c|}
\hline Driving cycle & $\begin{array}{c}\text { Distance } \\
\text { (miles) }\end{array}$ & $\begin{array}{c}\text { RMS error } \\
\text { Value }\end{array}$ & $\begin{array}{c}\text { Average Velocity } \\
\text { (mph) }\end{array}$ & $\begin{array}{c}\text { Stdev. of Velocity } \\
\text { (mph) }\end{array}$ \\
\hline Yard & 1.08 & 42.77 & 3.33 & 4.64 \\
\hline City-Suburban & 6.68 & 14.20 & 14.15 & 13.06 \\
\hline Freeway & 15.51 & 16.09 & 34.05 & 21.85 \\
\hline Driving cycle & $\begin{array}{c}\text { Idle } \\
\text { Time }\end{array}$ & $\begin{array}{c}\text { Deceleration } \\
\text { Time }\end{array}$ & $\begin{array}{c}\text { Average Deceleration } \\
\text { (mph/s) }\end{array}$ & $\begin{array}{c}\text { Stdev. of Deceleration } \\
\text { (mph/s) }\end{array}$ \\
\hline Yard & $38.83 \%$ & $11.60 \%$ & -0.989 & 0.650 \\
\hline City-Suburban & $19.82 \%$ & $23.94 \%$ & -1.183 & 0.651 \\
\hline Freeway & $7.87 \%$ & $24.02 \%$ & -0.642 & 0.541 \\
\hline Driving cycle & $\begin{array}{c}\text { Cruise } \\
\text { Time }\end{array}$ & $\begin{array}{c}\text { Acceleration } \\
\text { Time }\end{array}$ & $\begin{array}{c}\text { Average Acceleration } \\
\text { (mph/s) }\end{array}$ & $\begin{array}{c}\text { Stdev. of Acceleration } \\
\text { (mph/s) }\end{array}$ \\
\hline Yard & $31.70 \%$ & $17.87 \%$ & 0.6828 & 0.3544 \\
\hline City-Suburban & $22.06 \%$ & $34.18 \%$ & 0.8510 & 0.4984 \\
\hline Freeway & $36.04 \%$ & $32.07 \%$ & 0.5071 & 0.3117 \\
\hline
\end{tabular}


Figure 1. Scheduled speed vs. time trace for the Yard cycle. This cycle covers a distance of 1.08 miles in 1164 seconds, with a maximum speed of $16.8 \mathrm{mph}$.

$\longrightarrow$

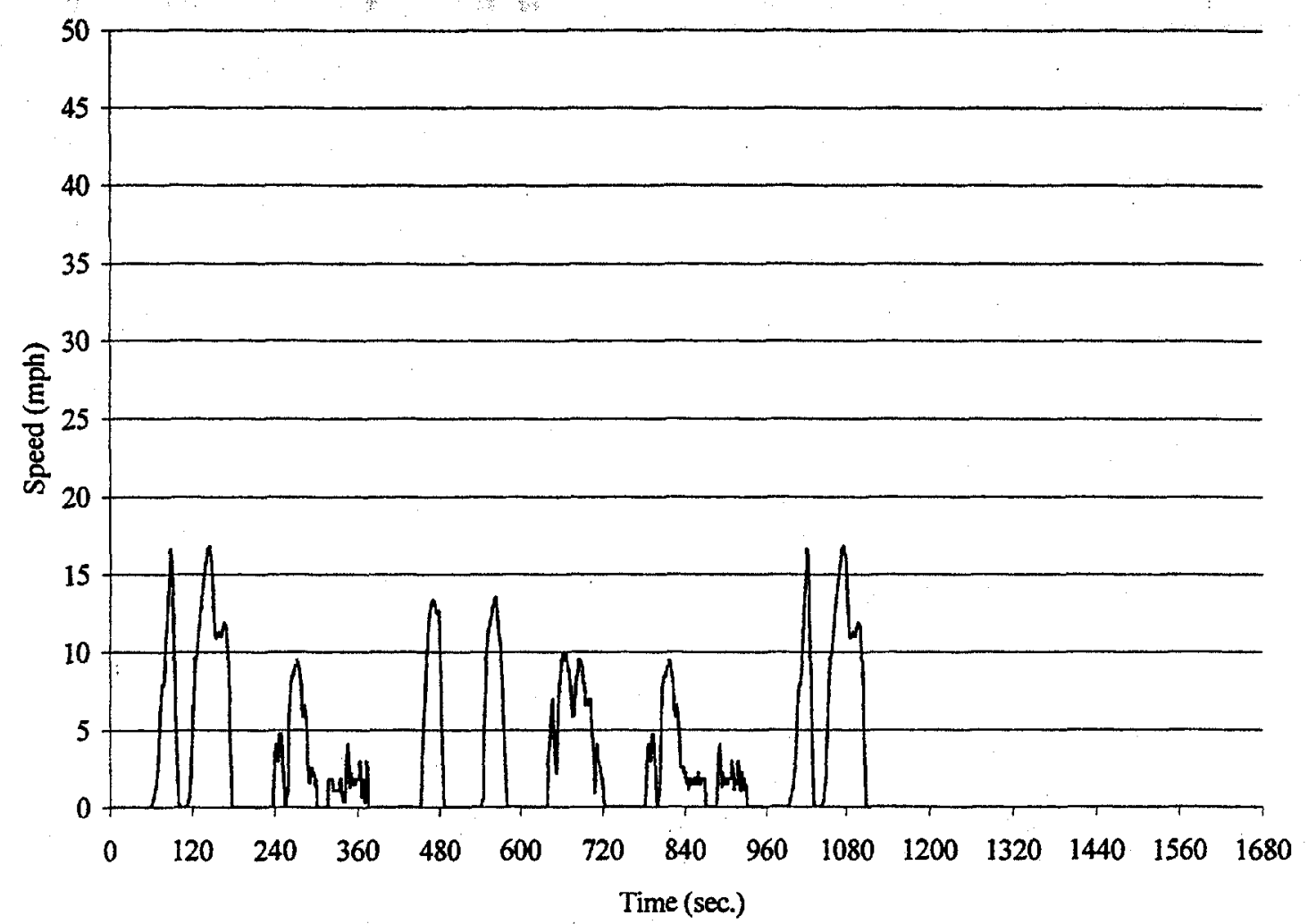

Figure 2. Scheduled speed vs. time trace for City-Suburban cycle. This cycle covers a distance of 6.68 miles in 1700 seconds, with a maximum speed of $43.8 \mathrm{mph}$.

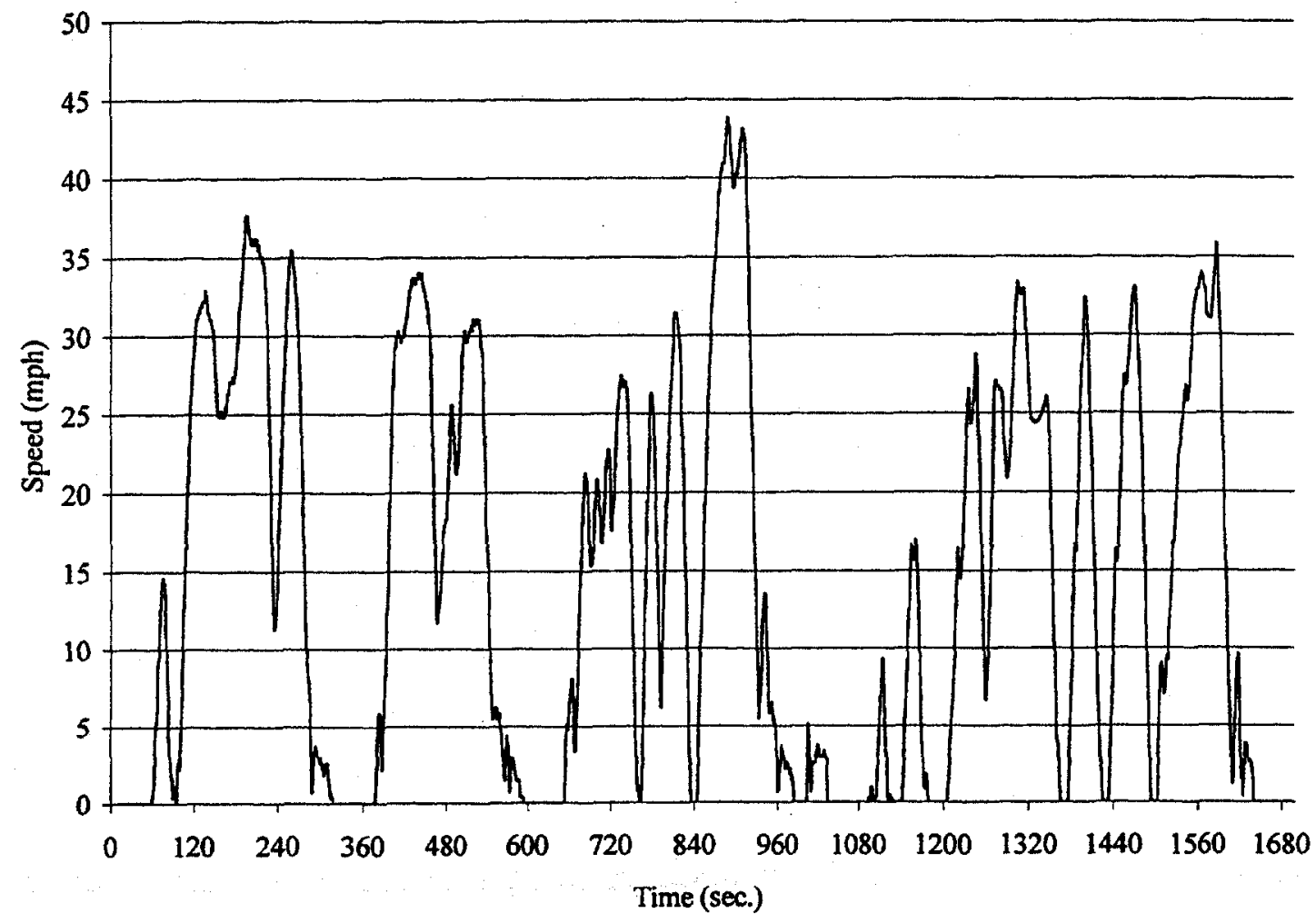


Figure 3. Scheduled speed vs. time trace for Freeway cycle. This cycle covers a distance of 15.51 miles in 1640 seconds, with a maximum speed of $60.7 \mathrm{mph}$.

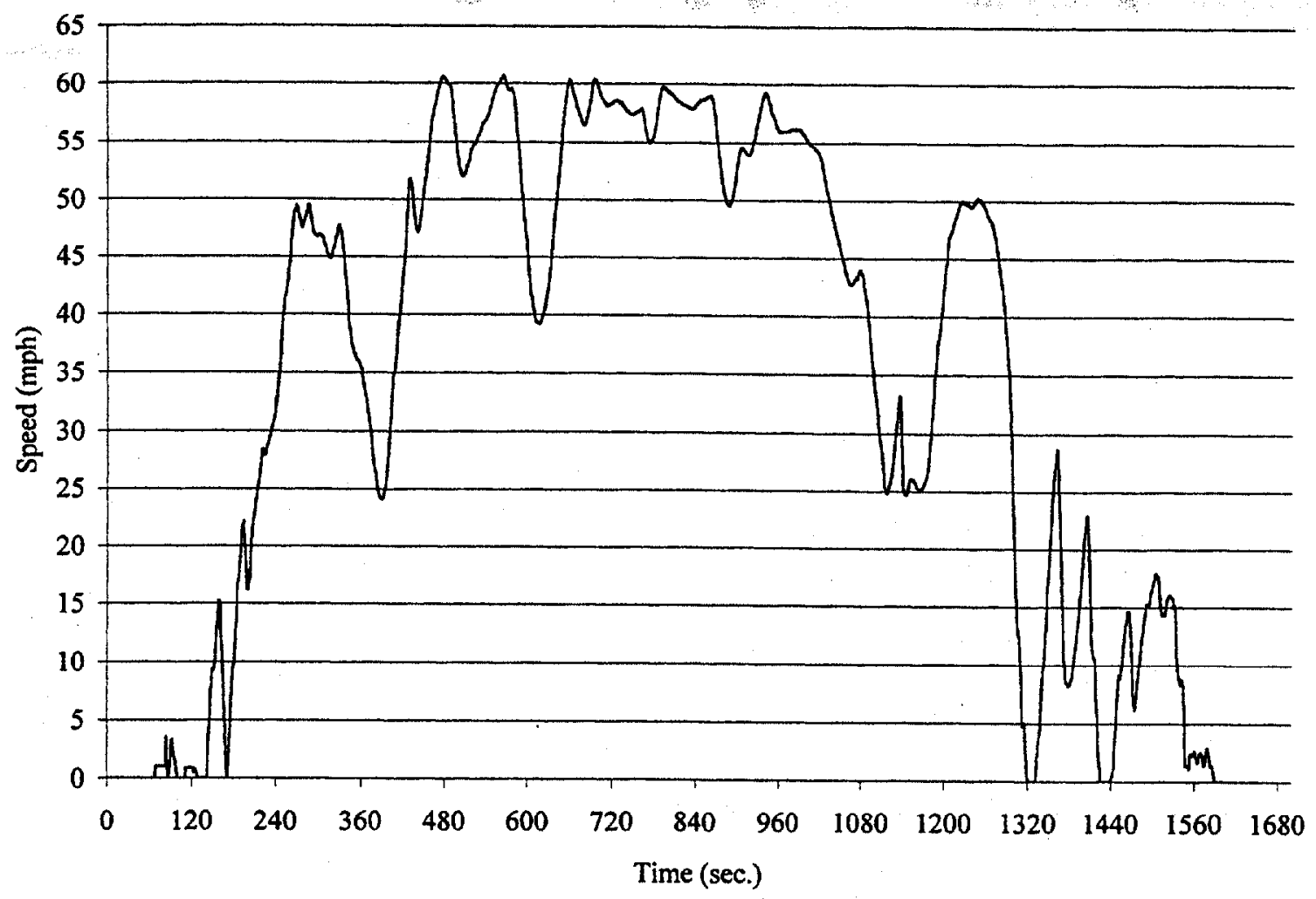

Table 3. Properties for run number 1126 of the CSHVR by the International tractor at a 46,400 lb. test weight.

\begin{tabular}{|c|c|c|c|c|}
\hline Route & $\begin{array}{c}\text { Distance } \\
\text { (miles) }\end{array}$ & $\begin{array}{c}\text { RMS error } \\
\text { Value }\end{array}$ & $\begin{array}{c}\text { Average Velocity } \\
\text { (mph) }\end{array}$ & $\begin{array}{c}\text { Stdev. of Velocity } \\
\text { (mph) }\end{array}$ \\
\hline City-Suburban & 6.69 & 14.20 & 14.60 & 12.92 \\
\hline Route & $\begin{array}{c}\text { Idle } \\
\text { Time }\end{array}$ & $\begin{array}{c}\text { Deceleration } \\
\text { Time }\end{array}$ & $\begin{array}{c}\text { Average Deceleration } \\
\text { (mph/s) }\end{array}$ & $\begin{array}{c}\text { Stdev. of Deceleration } \\
\text { (mph/s) }\end{array}$ \\
\hline City-Suburban & $18.24 \%$ & $26.00 \%$ & -1.06 & 0.55 \\
\hline Route & $\begin{array}{c}\text { Cruise } \\
\text { Time }\end{array}$ & $\begin{array}{c}\text { Acceleration } \\
\text { Time }\end{array}$ & $\begin{array}{c}\text { Average Acceleration } \\
\text { (mph/s) }\end{array}$ & $\begin{array}{c}\text { Stdev. of Acceleration } \\
\text { (mph/s) }\end{array}$ \\
\hline City-Suburban & $22.18 \%$ & $33.58 \%$ & 0.83 & 0.46 \\
\hline
\end{tabular}


Figure 4. Scheduled speed vs. distance trace for CSHVR. This route covers a distance of 6.68 miles with a maximum speed of $\mathbf{4 3 . 8} \mathbf{m p h}$. Idle times for the CSHVR are identical to the idle times in the City-Suburban cycle. However, they cannot be depicted on a speed vs. distance trace.

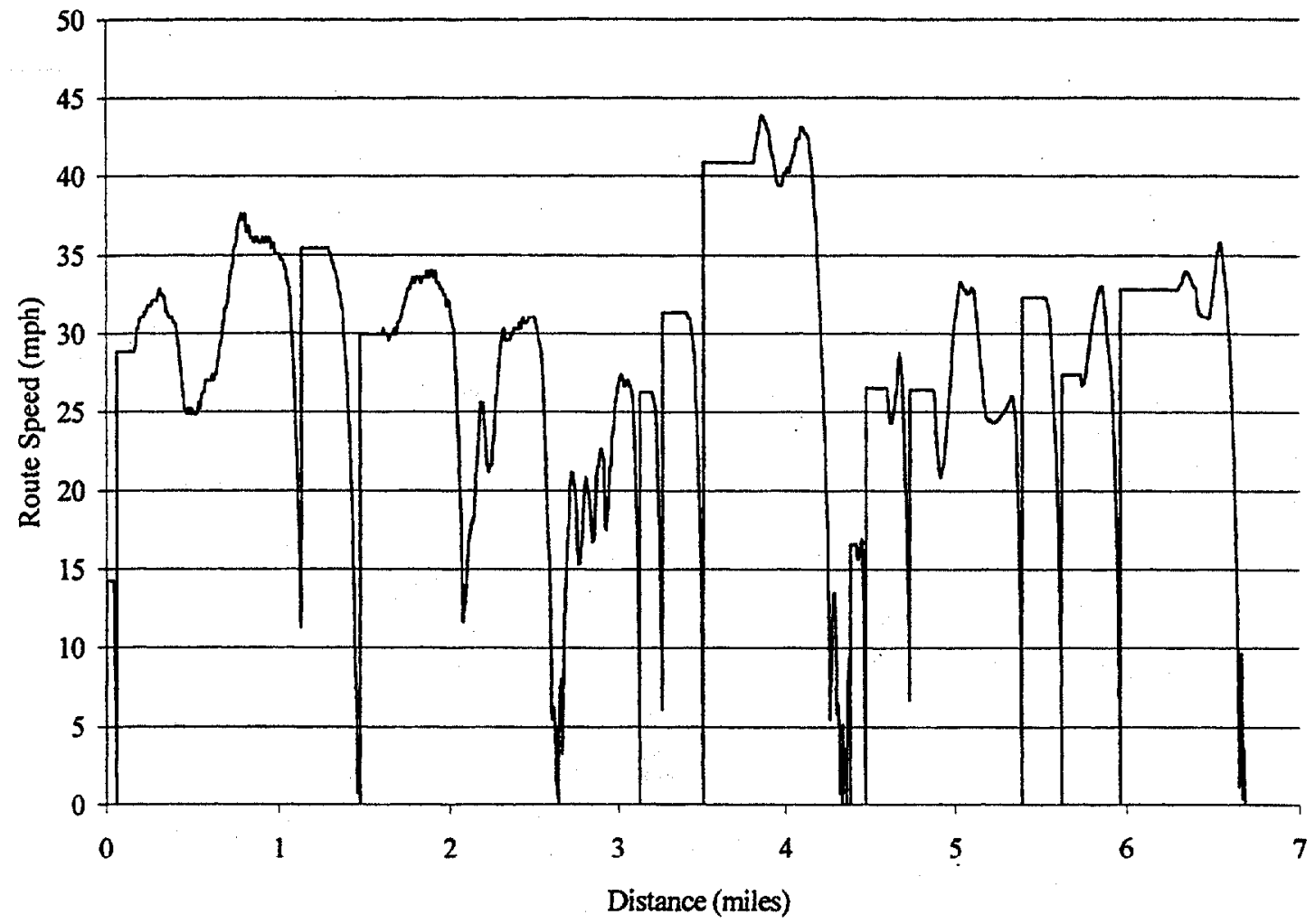

Table 4. Values for coefficlents used In road load equation.

\begin{tabular}{|l|c|c|}
\hline Coefficient & Ford L9000 & International Eagle \\
\hline$C_{d}$ & 0.79 & 0.79 \\
\hline$A\left(\mathrm{ft}^{2}\right)$ & 64 & 81 \\
\hline$\mu$ & 0.00938 & 0.00938 \\
\hline$\rho\left(\mathrm{lb} . \mathrm{ft}^{3}\right)$ & $73.5 \times 10^{-3}$ & $73.5 \times 10^{-3}$ \\
\hline$M(\mathrm{lbs})$ & 46000 & 46000 \\
\hline
\end{tabular}

\section{APPLICATION OF CYCLES AND ROUTE}

In practice, the vehicle is driven through a transient test by a human driver who is prompted by a driver's aid, or screen, which presents the driver with a target speed vs. time trace. In the case of a route, which is speed vs. distance based, the time axis on the driver's aid is expanded or contracted to account for faster or slower accelerations of the vehicle in practice. In other words, there is feedback from the dynamometer control system to alter the screen according to the cumulative distance traveled. The vehicle is assumed to be driven through the cycle using a mimicry of flat ground, so that the road load, excluding transient inertial effects, is given by equation (1):

$$
\text { Power }=0.5\left(C_{d} \rho A v^{3}\right)+M g \mu v
$$

The values used for drag coefficient $\left(C_{d}\right)$, frontal area $(A)$, tire rolling loss coefficient $(\mu)$, the air density $(\rho)$, the vehicle velocity $(v)$, and the vehicle mass $(M)$ in the present testing are shown in Table 4.

\section{DATA AND DISCUSSION}

\section{FORD TRACTOR}

The Ford tractor was driven through 4 repetitions of the CSHVR, 3 repetitions of the 5 peak cycle, 3 repetitions of the 5 mile route and 2 repetitions of the Heavy Duty Urban Dynamometer Driving Schedule. Tables 5 through 8 present the emissions data for the four cycles in units of $\mathrm{g} / \mathrm{mile}$. In Table 8 the difference as a percentage was calculated using the difference divided by the average. In the other tables, the coefficient of 
variance between runs is presented. In all cases the $\mathrm{CO}_{2}$ repeatability was outstanding, and the $\mathrm{NO}_{\mathrm{x}}$ repeatability was always below $5 \%$. Provided that jection timing does not change, the ratio of $\mathrm{NO}_{x}$ to $\mathrm{CO}_{2}$

known to be well defined for diesel engines (15). drocarbon emissions for this older truck were far higher than is generally encountered with advanced, electronically managed engines with high pressure injection, but repeatability for the HC was at worst $7.9 \%$ Higher test to test variations were encountered for $\mathrm{CO}$. $\mathrm{CO}$ is known to be highly sensitive to small changes in driving style, and responds in a non-linear fashion to power demand when near full load. This issue of $\mathrm{CO}$ sensitivity is the topic of another paper at this conference (16). PM varied in sympathy with the $C O$, and the explanation is similar to that for $\mathrm{CO}$ presented above. Table 5, for the CSHVR runs, shows a steadily declining trends in both the CO and PM emissions over the first three runs, that were conducted in sequence, and this trend continued with the fourth run, which was conducted four days later. All four runs had the same driver. This could be ascribed to the driver becoming used to the CSHVR, which was in its infancy at time of testing. As the driver learns the cycle; and becomes more relaxed, the rapidity and extent of pedal movement is expected to decrease, and this would result in a reduction in $\mathrm{CO}$ and PM emissions.

The differences in emissions between cycles merit discussion. The 5 mile route and 5 peak cycle yielded similar gaseous and PM emissions. This is because the Ford tractor was powered such that its full performance potential did not significantly outstrip the accelerations on the 5 peak cycle, so that the behaviors on the 5 mile route and 5 peak cycle were similar. The fifth peak of the 5 mile route ended (i.e. the truck returned to idle) at 790 seconds from the start of the test, while the equivalent time for the 5 peak cycle was 817 seconds. Graboski et al. (12) have commented previousiy that the 5 peak cycle yielded lower emissions than the Urban Dynamometer Driving Schedule and this was borne out by the present data. The $\mathrm{NO}_{x}$ for Urban Dynamometer Driving Schedule was $46 \%$ higher than for the 5 peak cycle, while $C O$ was almost twice as high. Curiously, the PM was not raised much, and this may be attributed to the style of fuel injection, which could encourage high soluble organic content of PM at low loadings. The new CSHVR yielded the highest emissions of all four test schedules. The $\mathrm{NO}_{x}$ emissions were $63 \%$ higher than for the 5 mile route and $13 \%$ higher than for EPA Urban Dynamometer Driving Schedule for Heavy Duty Vehicles. The PM emissions for the CSHVR were about $40 \%$ higher than for the other three test schedules. Since the CSHVR was derived from actual, recent urban and suburban truck behavior, this implies that present day emissions inventories may be higher than would be estimated from previous chassis test schedules.

ble 5. Emissions results from 4 repetitions of the CSHVR driven by the Ford tractor at a simulated test weight of 46,400 lbs.

\begin{tabular}{|l|c|c|c|c|c|c|c|}
\hline & $1091-1$ & $1091-2$ & $1091-3$ & $1094-1$ & Average & Stdev. & COV \\
\hline $\mathrm{CO}$ (g/mile) & 34.76 & 29.55 & 30.76 & 27.02 & 30.52 & 3.23 & $10.6 \%$ \\
\hline $\mathrm{NO}_{\mathbf{x}}$ (g/mile) & 32.16 & 34.13 & 32.12 & 30.80 & 32.30 & 1.38 & $4.3 \%$ \\
\hline $\mathrm{HC}$ (g/mile) & 4.43 & 3.91 & 4.01 & 3.67 & 4.01 & 0.32 & $7.9 \%$ \\
\hline $\mathrm{PM}$ (g/mile) & 7.69 & 6.02 & 6.34 & 5.38 & 6.35 & 0.97 & $15.3 \%$ \\
\hline $\mathrm{CO}_{2}$ (g/mile) & 2987 & 2843 & 2925 & 2936 & 2923 & 59.79 & $2.0 \%$ \\
\hline
\end{tabular}

Table 6. Emissions results from 3 repetitions of the 5 peak cycle driven by the Ford tractor at a simulated test weight of $46,400 \mathrm{lbs}$.

\begin{tabular}{|l|c|c|c|c|c|c|c|}
\hline & $1089-1$ & $1089-2$ & $1089-3$ & $1089-4$ & Average & Stdev. & $\mathrm{COV}$ \\
\hline $\mathrm{CO}$ (g/mile) & 11.78 & 11.13 & 12.82 & 12.75 & 12.12 & 0.95 & $7.9 \%$ \\
\hline $\mathrm{NO}_{\mathbf{x}}$ (g/mile) & 20.24 & 19.32 & 19.86 & 19.97 & 19.85 & 0.34 & $1.7 \%$ \\
\hline $\mathrm{HC}$ (g/mile) & 2.12 & 2.02 & 2.23 & 2.04 & 2.10 & 0.11 & $5.5 \%$ \\
\hline $\mathrm{PM}$ (g/mile) & 5.48 & 3.91 & 4.67 & 4.46 & 4.63 & 0.39 & $8.5 \%$ \\
\hline $\mathrm{CO}_{2}$ (g/mile) & 2237 & 2130 & 2212 & 2117 & 2174 & 51.94 & $2.4 \%$ \\
\hline
\end{tabular}

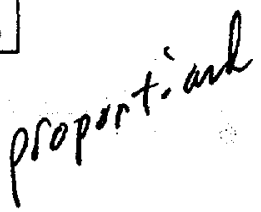


Table 7. Emissions results from 3 repetitions of the 5 mile route driven by the Ford tractor at a simulated test weight of $46,400 \mathrm{lbs}$.

weight of 46,400 lbs.
\begin{tabular}{|l|c|c|c|c|c|c|}
\hline & $1092-1$ & $1092-2$ & $1092-3$ & Average & Stdev. & COV \\
\hline $\mathrm{CO}_{\text {(g/mile) }}$ & 11.91 & 12.86 & 13.47 & 12.75 & 0.78 & $6.2 \%$ \\
\hline $\mathrm{NO}_{\mathrm{x}}$ (g/mile) & 22.66 & 21.56 & 21.68 & 21.96 & 0.60 & $2.8 \%$ \\
\hline $\mathrm{HC}$ (g/mile) & 2.12 & 2.14 & 2.22 & 2.16 & 0.05 & $2.4 \%$ \\
\hline $\mathrm{PM}$ (g/mile) & 4.84 & 4.47 & 4.69 & 4.67 & 0.19 & $4.1 \%$ \\
\hline $\mathrm{CO}_{2}$ (g/mile) & 2293 & 2316 & 2356 & 2322 & 32.24 & $1.4 \%$ \\
\hline
\end{tabular}

Table 8. Emissions results from 2 repetitions of the Urban Dynamometer Driving Schedule driven by the Ford tractor at a simulated test weight of $46,400 \mathrm{lbs}$.

\begin{tabular}{|l|c|c|c|c|}
\hline & $1093-1$ & $1093-2$ & Average & Difference \\
\hline $\mathrm{CO}$ (g/mile) & 20.33 & 23.04 & 21.69 & $-12.5 \%$ \\
\hline $\mathrm{NO}_{\mathbf{x}}$ (g/mile) & 29.41 & 28.72 & 29.07 & $2.4 \%$ \\
\hline $\mathrm{HC}$ (g/mile) & 3.09 & 3.00 & 3.04 & $3.0 \%$ \\
\hline $\mathrm{PM}$ (g/mile) & 4.67 & 4.58 & 4.62 & $2.0 \%$ \\
\hline $\mathrm{CO}_{2}$ (g/mile) & 2608 & 2543 & 2576 & $2.5 \%$ \\
\hline
\end{tabular}

\section{INTERNATIONAL TRACTOR}

The International tractor was exercised through the CSHVR, the new City-Suburban cycle, the WVU 5- Mile Route; the new Yard cycle and the new Freeway cycle. The Freeway cycle was driven by a different driver than the driver for the other cycles and the CSHVR was driven by several drivers, as shown in Figure 10. Time constraints forbade repetitions of the last three schedules, but the test to test repeatability found using the Ford tractor gave confidence that the test data would be representative. Figure 5 and Figure 6 present the actual speed versus time trace and the instantaneous measured $\mathrm{NO}_{x}$ versus time trace for the International tractor performing the CSHVR. Figure 7 shows engine speed for the same run, while Figures 8 and 9 show the axle torque and the ratio of vehicle speed to engine speed respectively. Figure 9 reflects the instantaneous choice of gear. This newer tractor yielded $\mathrm{NO}_{\mathrm{x}}$ emissions that were similar to those of the Ford tractor on the 5 mile route, and PM was cut by an order of magnitude, as shown in Table 9. For the 5 mile route, $\mathrm{CO}_{2}$ and $\mathrm{NO} \times$ were again highly repeatable, but variation between the two tests was evident for $\mathrm{CO}$ and PM. Once again, $\mathrm{CO}$ and $\mathrm{PM}$ varied in sympathy.

Tables 10, 12 and 11 present the remaining data for the International tractor on the Yard, Freeway and City-Suburban cycles. The NOx level for the CitySuburban cycle was $19 \%$ higher than for the 5 mile route and PM was about $50 \%$ higher. The yard cycle yielded high PM and $\mathrm{NO}_{x}$ emissions, partly because little distance is traveled for the power expended. The Freeway cycle yielded low PM emissions but high $\mathrm{NO}_{\mathrm{x}}$ emissions, which might be attributed to an off-cycle injection timing strategy (15).

The CSHVR, averaged for all drivers, as shown in Figure 10, yielded $\mathrm{NO}_{x}$ emissions that were similar to the cycle from which it was derived. Although PM emissions were slightly higher, it is not fitting to reach a conclusion on PM since only one cycle was performed and since the coefficient of variance was $12.5 \%$ for the route. $\mathrm{CO}$ emissions were also slightly higher but the $\mathrm{HC}$ difference was small. 
Table 9. Emissions results from 2 runs of the WVU 5-Mile Route driving, by the International tractor at a simulated test weight of 46,400 lbs.

\begin{tabular}{|c|c|c|c|c|}
\hline & 1121 & 1123 & Average & Difference \\
\hline $\mathrm{CO}$ (g/mile) & 3.75 & 2.75 & 3.25 & $30.8 \%$ \\
\hline $\mathrm{NO}_{\mathrm{x}}$ (g/mile) & 20.1 & 19.8 & 19.95 & $1.5 \%$ \\
\hline $\mathrm{HC}$ (g/mile) & 1.7 & 1.73 & 1.715 & $-1.7 \%$ \\
\hline $\mathrm{PM}$ (g/mile) & 0.51 & 0.33 & 0.42 & $42.9 \%$ \\
\hline $\mathrm{CO}_{2}$ (g/mile) & 1880 & 1892 & 1886 & $-0.6 \%$ \\
\hline
\end{tabular}

Table 10. Emissions results from one Yard Cycle driving by the International tractor at a simulated test weight of $46,400 \mathrm{lbs}$.

\begin{tabular}{|c|c|}
\hline & 1147 \\
\hline $\mathrm{CO}$ (g/mile) & 15 \\
\hline $\mathrm{NO}_{\mathbf{x}}$ (g/mile) & 52.9 \\
\hline $\mathrm{HC}$ (g/mile) & 6.57 \\
\hline $\mathrm{PM}$ (g/mile) & 1.00 \\
\hline $\mathrm{CO}_{2}$ (g/mile) & 4051 \\
\hline
\end{tabular}

Table 11. Emissions results from one CitySuburban Cycle driving, by the international tractor at a simulated test weight of $46,400 \mathrm{lbs}$.

\begin{tabular}{|c|c|}
\hline & 1148 \\
\hline $\mathrm{CO}$ (g/mile) & 4.93 \\
\hline $\mathrm{NO}_{\mathrm{X}}$ (g/mile) & 23.7 \\
\hline $\mathrm{HC}$ (g/mile) & 1.79 \\
\hline $\mathrm{PM}$ (g/mile) & 0.64 \\
\hline $\mathrm{CO}_{2}$ (g/mile) & 2444 \\
\hline
\end{tabular}

Table 12. Emissions results from one Freeway Cycle driving, by the International tractor at a simulated test weight of 46,400 lbs.

\begin{tabular}{|c|c|}
\hline & 1157 \\
\hline $\mathrm{CO}$ (g/mile) & 2.33 \\
\hline $\mathrm{NO}$ (g/mile) & 30.2 \\
\hline $\mathrm{HC}$ (g/mile) & 0.91 \\
\hline $\mathrm{PM}$ (g/mile) & 0.35 \\
\hline $\mathrm{CO}_{2}$ (g/mile) & 1485 \\
\hline
\end{tabular}

Table 13. Emissions results from 5 repetitions of the CSHVR driving by the International tractor at a simulated test weight of $46,400 \mathrm{lbs}$.

\begin{tabular}{|l|c|c|c|c|c|c|c|c|}
\hline & $1122-1$ & $1122-2$ & $1122-3$ & 1126 & 1131 & Average & Stdev. & COV \\
\hline $\mathrm{CO}$ (g/mile) & 6.48 & 5.93 & 5.67 & 5.52 & 5.20 & 5.76 & 0.48 & $8.4 \%$ \\
\hline $\mathrm{NO}_{\mathrm{x}}$ (g/mile) & 23.60 & 23.20 & 23.00 & 24.40 & 22.50 & 23.34 & 0.71 & $3.1 \%$ \\
\hline $\mathrm{HC}$ (g/mile) & 1.95 & 2.01 & 1.98 & 1.89 & 1.82 & 1.93 & 0.08 & $3.9 \%$ \\
\hline $\mathrm{PM}$ (g/mile) & 0.80 & 0.77 & 0.76 & 0.60 & 0.63 & 0.71 & 0.09 & $12.5 \%$ \\
\hline $\mathrm{CO}_{2}$ (g/mile) & 2565 & 2572 & 2553 & 2511 & 2412 & 2523 & 66.20 & $2.6 \%$ \\
\hline
\end{tabular}

Repeatability of the emissions generated from cycles and route was demonstrated by monitoring the coefficient of variance for a set of repeat runs: Table 13 shows the data from repeat runs, all executed by the same driver, for the International truck on the CSHVR. 
Figure 5. Continuous speed vs. time trace of run 1126 of the CSHVR driving by the International tractor at a simulated test weight of $46,400 \mathrm{lbs}$.

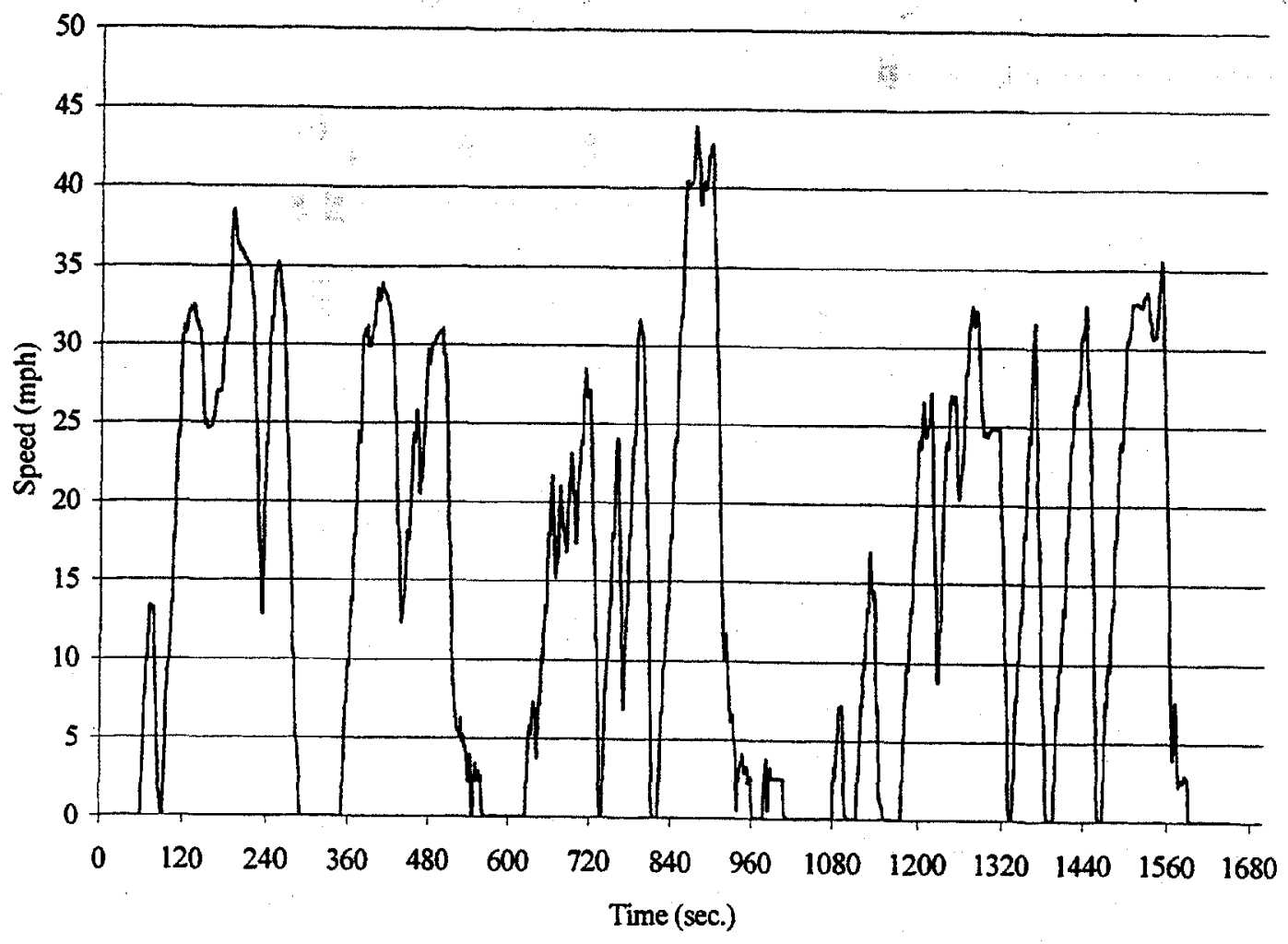

Figure 6. Continuous $\mathrm{NO}_{x}$ trace of run 1126 of the CSHVR driving by the International tractor at a simulated test weight of $46,400 \mathrm{lbs}$.

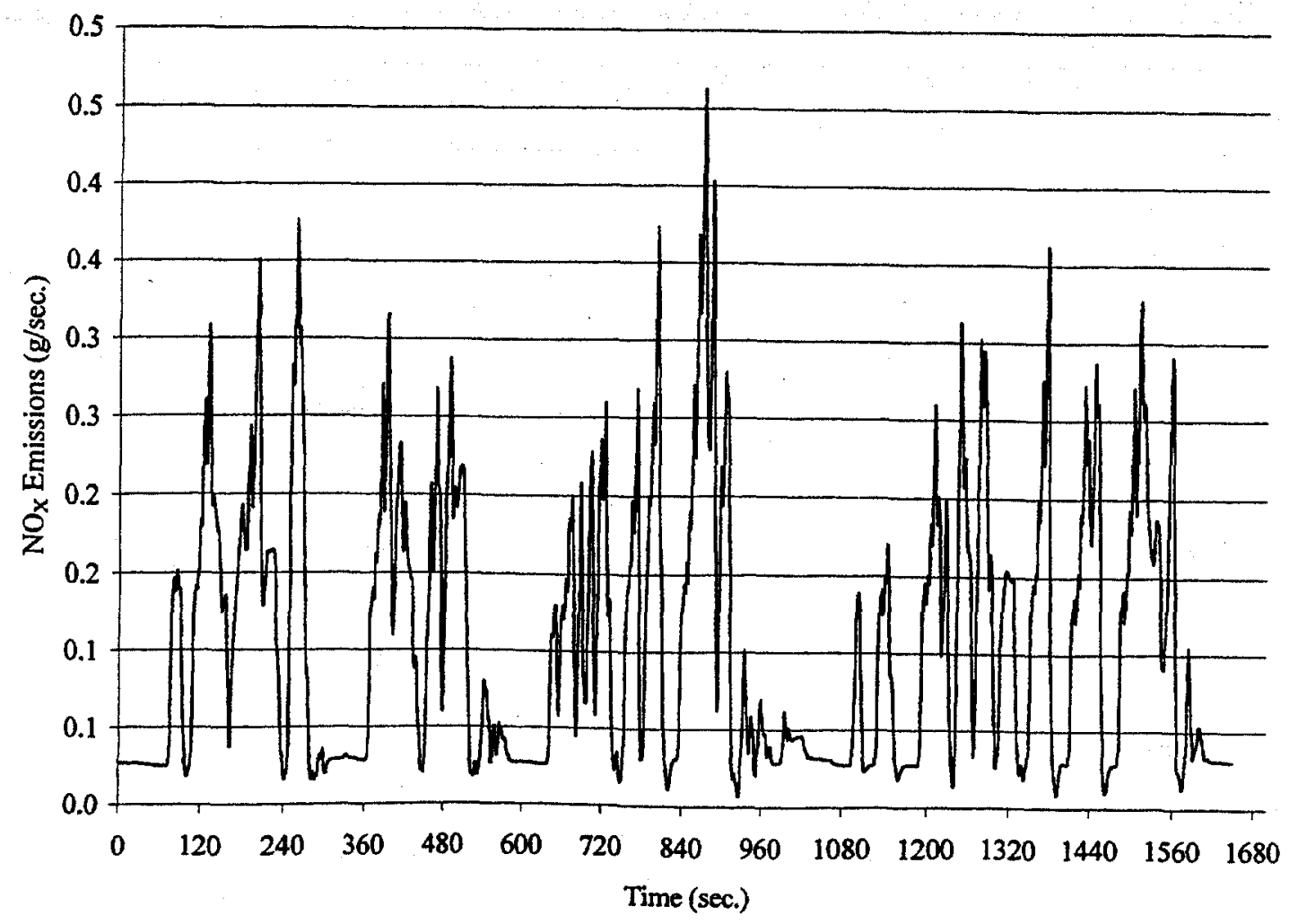


Figure 7. Continuous engine speed trace of run 1126 of the CSHVR driving by the International tractor at a simulated test weight of 46,400 lbs.

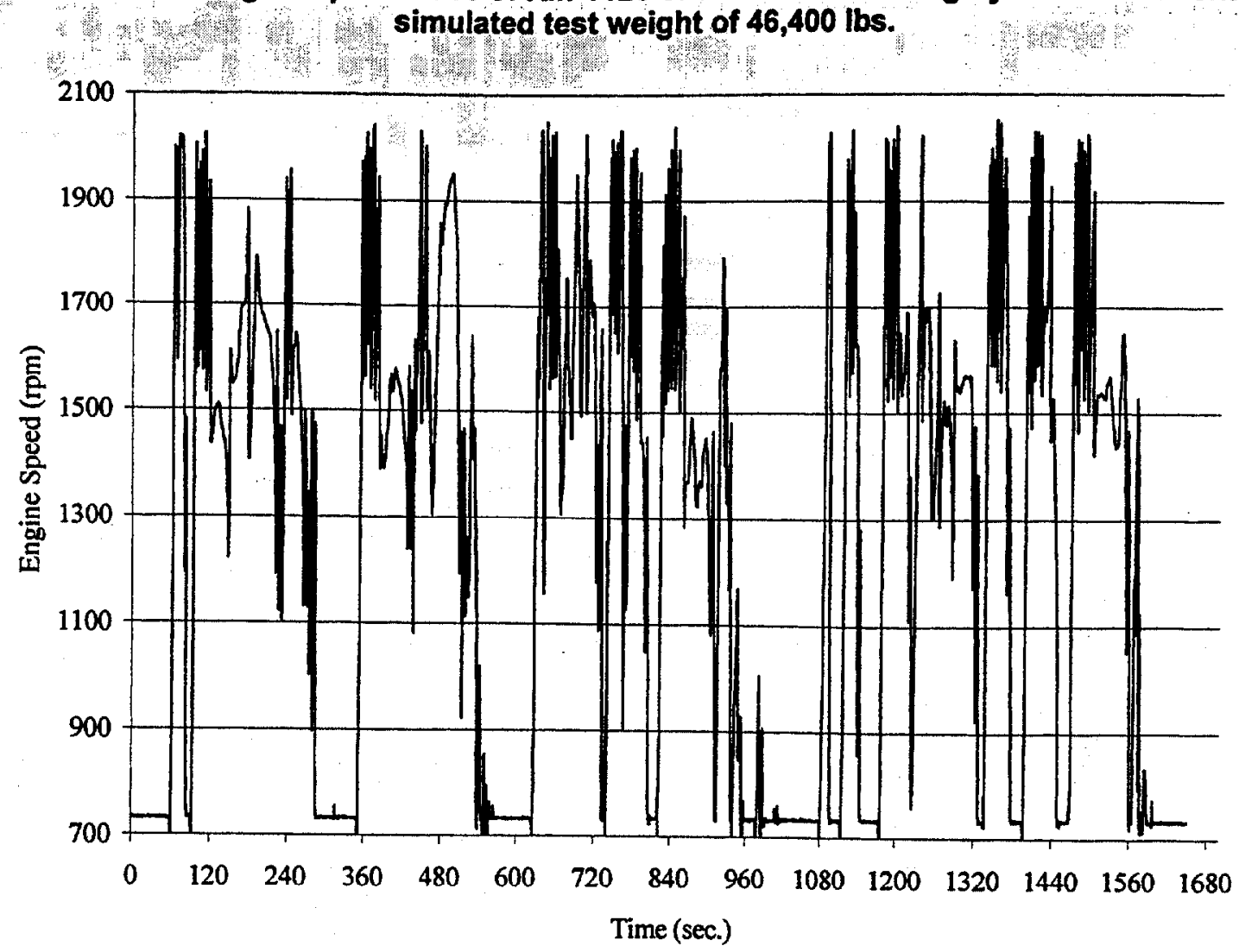

Figure 8. Continuous axle torque trace of run 1126 of the CSHVR driving by the International tractor at a simulated test weight of $\mathbf{4 6 , 4 0 0}$ lbs.

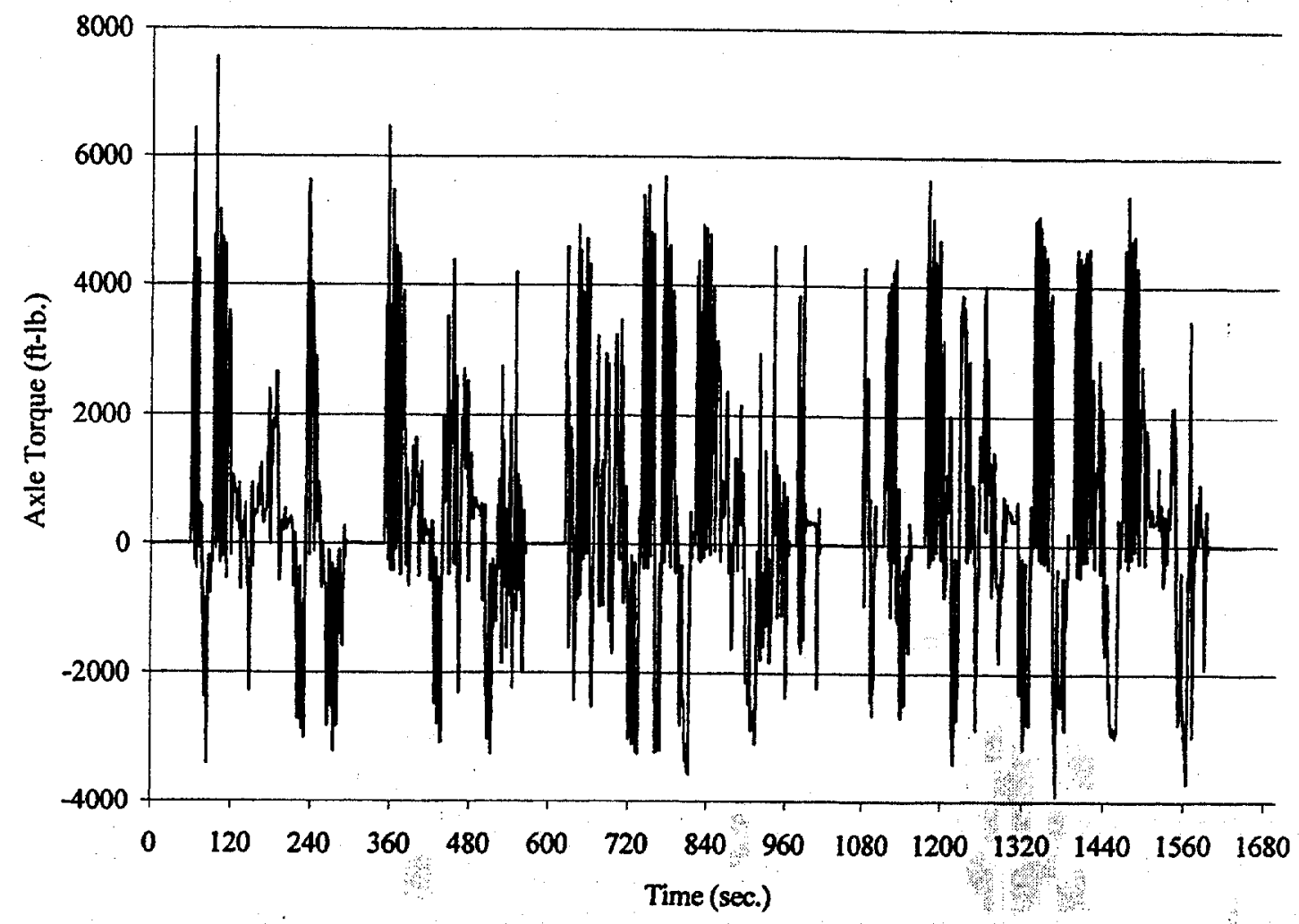


Figure 9. Continuous ratio of vehicle speed to rotational engine speed trace of run 1126 of the CSHVR driving by the International tractor at a simulated test weight of $46,400 \mathrm{lbs}$.

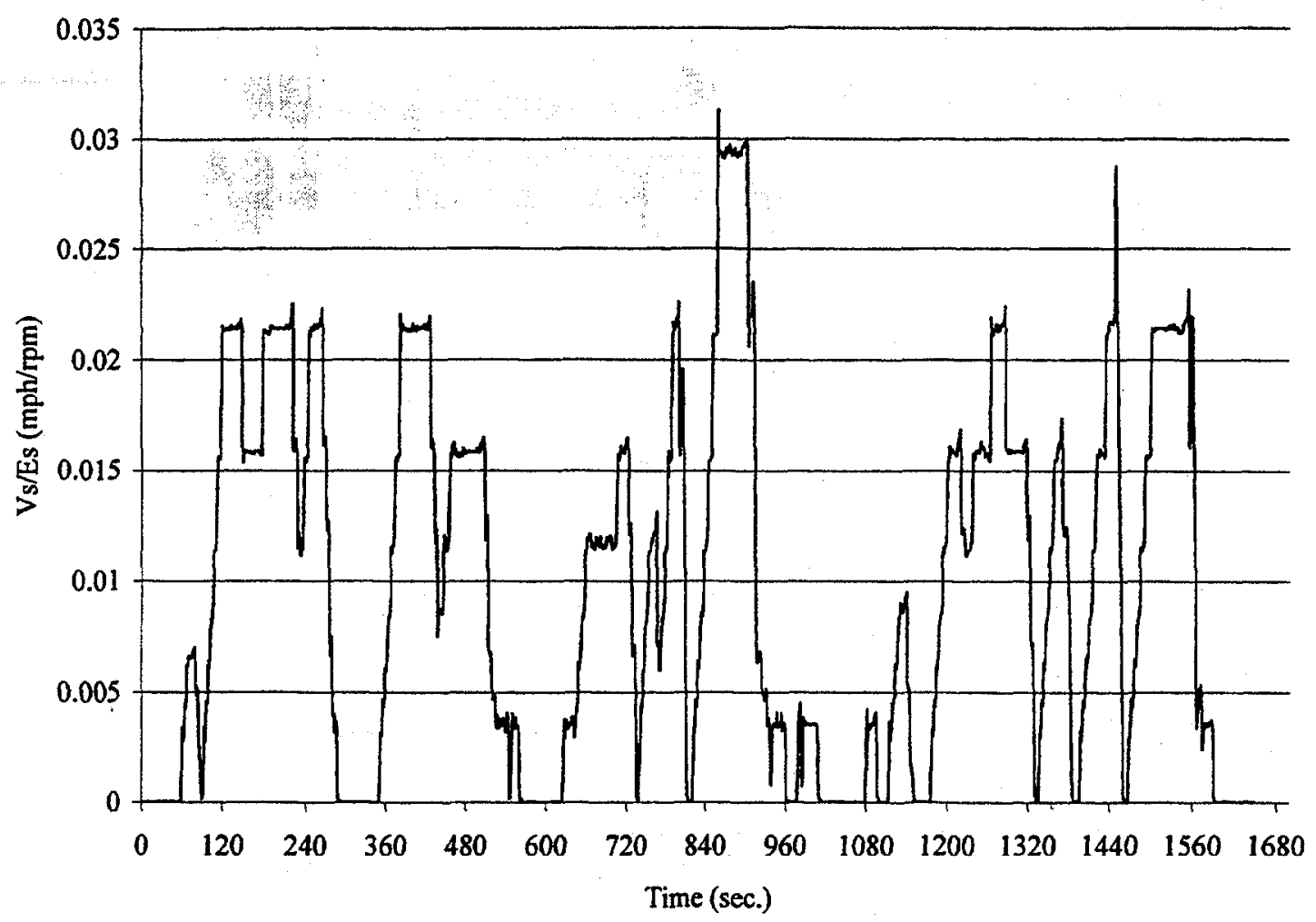

Figure 10. Comparisons between three drivers, driving the CSHVR using an International road tractor at a 46,400 lb. test weight.

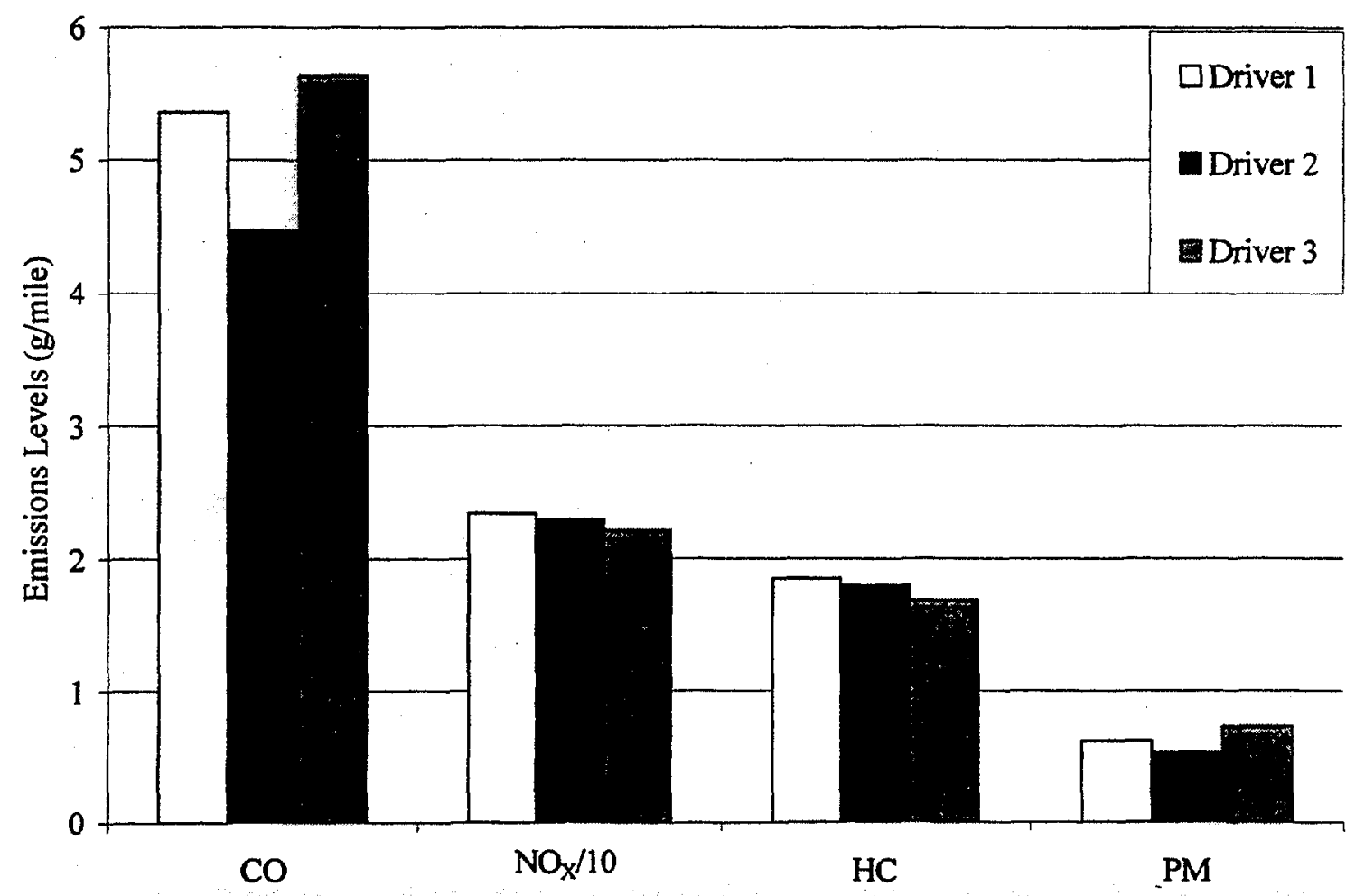


Driver-to-driver variations were evaluated using three drivers. Each driver held a commercial driver's cense (CDL). All driver-to-driver variation tests were completed during one day of testing in order to eliminate variations from day-to-day. The drivers' driving order was selected randomly so that influence of other variables could be reduced. Driver-to-driver variation tests were completed using the International tractor at a $46,400 \mathrm{lb}$. test weight. Figure 10 shows the average emissions results of each driver running the CSHVR. The $\mathrm{NO}_{x}$ emissions varied little between drivers, but the driving styles influenced $\mathrm{CO}$ and $\mathrm{PM}$, which varied in sympathy with one another. Nevertheless, the coefficient of variance (as a percentage) for $\mathrm{CO}$ between drivers was $11.1 \%$ and for PM was $14.8 \%$, which the authors believe to be an acceptable variation for diesel fueled vehicles. The main difference in the driver-todriver emissions results is due to the aggressiveness of each driving style on the chassis dynamometer. Vehicle shifting patterns are also different when the vehicle is operated by different drivers. This is shown by plotting a vehicle speed engine speed (Vs/Es) ratio as displayed in Figure 10. The Vs/Es ratio is constant when a driver is locked into a certain gear. During shifting the ratio is not constant and is shown as an instantaneous change in the Vs/Es ratio. This ratio can be used when comparing a single driver for repeatable driving behavior or when comparing the driving patterns of two different drivers operating vehicles with unsynchronized transmissions. This ratio will show clear differences when drivers follow the same section of the CSHVR in a different gear. In the future it may become possible to reduce variation by prescribing gear selection, but such a prescription remains more difficult with heavy duty than light duty vehicles.

Figure 11. Vehicle speed/ Engine speed ratio used to show differences in vehicle shifting patterns between different drivers.

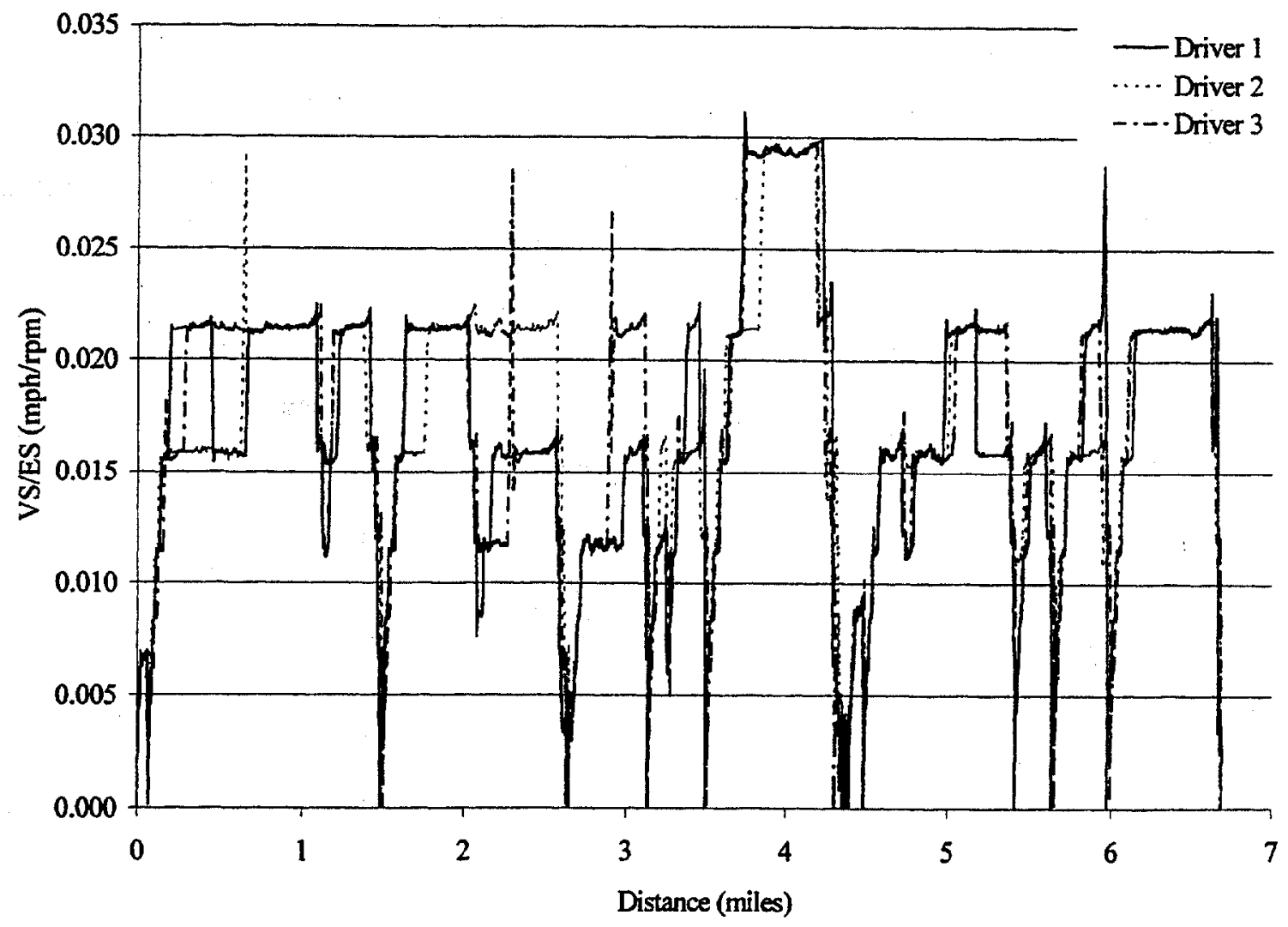


Figure 12. Average emissions results using three different simulated test weights. Tests were performed using the International tractor at a simulated weight of $46,400 \mathrm{lbs} ., 36,000 \mathrm{lbs}$. and $26,000 \mathrm{lbs}$.

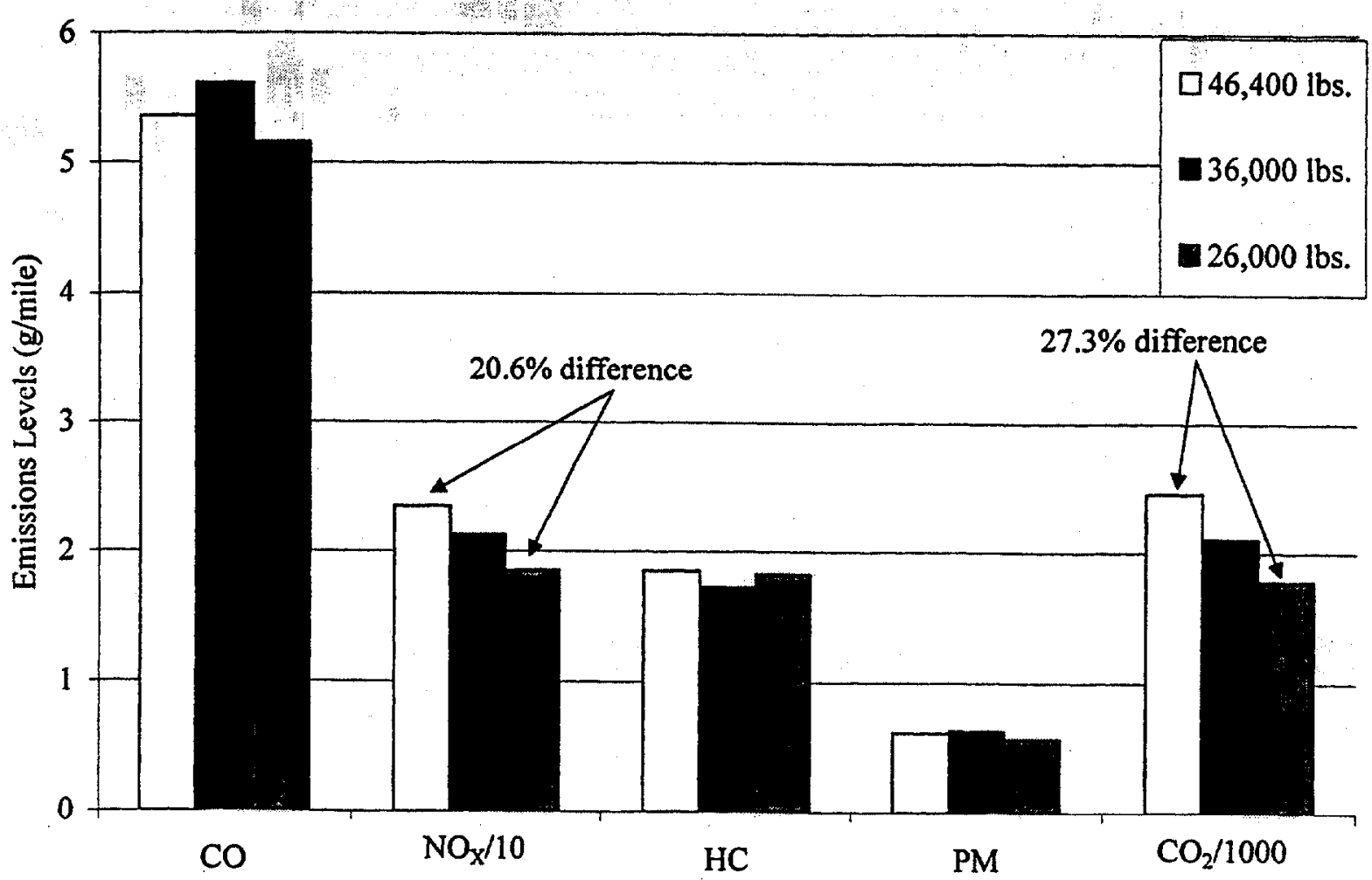

The effect of test weight on emissions, in units of mass/distance, was assessed using the International tractor with the CSHVR at $26,000,36,000$ and $46,400 \mathrm{lb}$. test weights as shown in Figure 12 . Variation of all regulated exhaust emissions was modest between test weights, although the $\mathrm{CO}_{2}$ level reflected the additional energy used at higher weights. The small variation in $\mathrm{CO}$ and PM emissions may be attributed to the fact that in all three cases, the route called for full power operation of the vehicle and demanded a similar number of shifts with associated transient $\mathrm{CO}$ and PM emissions. Also, the wind resistance component remained the same regardless of test weight. Emissions of $\mathrm{NO}_{x}$ were reduced by $20.6 \%$ as the test weight was reduced by $44 \%$, from 46,400 to $26,000 \mathrm{lb}$. The $\mathrm{NO}_{x} / \mathrm{CO}_{2}$ ratio varied little, from 0.0095 at $46,400 \mathrm{lb}$. to 0.0104 at $26,000 \mathrm{lb}$.

\section{CONCLUSIONS}

Over the road tractors have been exercised through a new Yard cycle, a new Freeway cycle, a new City-Suburban cycle and a new City-Suburban Heavy Vehicle Route (CSHVR), as well as cycles already in use for heavy truck emissions characterization. In the case of the tractor with an electronically managed engine, the Yard cycle returned the highest NOx and PM emissions in units of $\mathrm{g} / \mathrm{mile}$, because little distance is traveled. The Freeway cycle yielded high $\mathrm{NO}_{x}$ but low PM relative to both the City-Suburban cycle and CSHVR. Repeatability of the CSHVR was excellent for $\mathrm{CO}_{2}$ and $\mathrm{NO}_{\mathrm{x}}$ and coefficients of variation among five runs were $8.4 \%$ for
CO and $12.5 \%$ for PM which is considered acceptable for diesel engines, which have high $\mathrm{CO}$ and $\mathrm{PM}$ sensitivity. Driver-to-driver variations were also higher for PM than for $N O_{x}$. The CSHVR proved relatively insensitive, in the emissions that it yieided, to the test weight, with $\mathrm{NO}_{x}$ showing the greatest variation and $\mathrm{CO}_{2}$ levels reflecting the energy consumed. Following this preliminary testing effort, the CSHVR has now been applied in field emissions characterization. It is concluded that the CSHVR represents a useful and realistic test schedule for truck emissions characterization.

\section{ACKNOWLEDGEMENTS}

The authors are grateful to the National Renewable Energy Laboratory (NREL) for support of this research and to Paul Norton and Charles White of NREL for their guidance. Victor Suski of the American Trucking Association has provided valuable assistance, as have the researchers of the WWU Transportable Laboratories.

\section{CONTACT INFORMATION}

Contact Nigel N. Clark, Department of Mechanical and Aerospace Engineering, PO Box 6106, Morgantown, WV 26506, (304) 293-3111 ext. 2463, nclark@wvu.edu. 


\section{REFERENCES}

1. Bechtold, R. L., "Alternative Fuels Guidebook: Droperties, Storage, Dispensing, and Vehicle Facility Lodifications", Library of Congress Cataloging-inlication Data, TP343.B37, 1997.

2. Graboski, M. S., Ross, J. D., McCormick, R. L., "Transient Emissions from No. 2 Diesel and Biodiesel Blends in a DDC Series 60 Engine", SAE Paper 961166 , 1996.

3. Schaberg, P., Myburgh, I., Botha, J., Roets, P., Vijoen, C., Dancuart, L., and Starr, M., "Diesel Exhaust Emissions Using Sasol Slurry Phase Distillate Process Fuels", SAE Paper 972889, 1989.

4. Bertilsson, B. and Gustavsson, L., "Experience of Heavy-Duty Alcohol-Fueled Diesel-Ignition Engines", SAE Paper 871672, 1987.

5. Baranescu, R., Hilger, U., Bartunek, B., Scheid, E., Pischinger, F., Rogers, G., Last, R., "Prototype Development of a Methanol Engine for Heavy-Duty Application-Performance and Emissions", SAE Paper 891653, 1989.

6. Clark, N. N., Gautam, M., Lyons, D.W., Bata, R. M., Wang, W. G., "Natural Gas and Diesel Transit Bus Emissions: Review and Recent Data", SAE Paper 73203, 1997.

Clark, N. N., Rapp, B.L., Gautam, M., Wang, W. G. Lyons, D.W., "A Long Term Field Emissions Study of Natural Gas Fueled Refuse Haulers in New York City", SAE Paper 982456, 1998.

8. Clark N. N., Nine R. D., Daley, J. J., "Development of a Heavy Duty Chassis Dynamometer Driving Route", Journal of Automobile Engineering, Currently Under Review, 1999.

9. Daley, J. J., "Development of a Heavy Duty Vehicle Chassis Dynamometer Test Route", MS Thesis, West Virginia University, Morgantown, WV., 1998.

10. Clark, N. N., McKain, D. L., Messer, J. T., Lyons, D. W., "Chassis Test Cycles for Assessing Emissions From Heavy Duty Trucks", SAE Paper 941946, 1994.

11. Clark, N. N. and Lyons, D. W., "Class 8 Truck Emissions Testing: Effects of Test Cycles and Data on Biodiesel Operation" American Society of Agricultural Engineers Meeting, Orlando, FI., 1998. ASAE paper 986082.

12. Graboski M. S., Yanowitz, J., McCormick, R. L., "Inhe Emissions From Heavy-Duty Vehicles Operating in Colorado Northern Front Range Area", $8^{\text {th }}$ CRC Onroad Vehicle Emissions Workshop, San Diego, CA., 1998.
13. Clark, N. N., Nine, R. D., Daley, J. J., Atkinson, C. M., Tennant, C. J., Lyons, D. W., Peerenboom, W. H., Suski, V. A., "Heavy Duty Truck Emissions: Driving Routes and $\mathrm{NO}^{-N} \mathrm{H}_{2}$ Ratios", 8 th $\mathrm{CRC}$ On-Road Vehicle Emissions Workshop, San Diego, CA., 1998.

14. Clark, N. N., Messer, J. T., McKain, D. L., Wang, W.G., Bata, R. M., Gautam, M., Lyons, D. W., "Use of the West Virginia University Truck Test Cycle to Evaluate Emissions from Class 8 Trucksn, SAE Paper 951016, 1995.

15. Ramamurthy, R., and Clark, N. N., "Atmospheric Emissions Inventory Data for Heavy Duty Vehicles", Environmental Science and Technology, in Press, to appear January 1999.

16. Clark, N. N., Gautam, M., Rapp, B.L., Lyons, D.W., Graboski, M. S., McCormick, R.L., Alleman, T.L., and Norton, P." "Transit Bus Emissions Characterization by Two Chassis Dynamometer Laboratories: Results and Issues", SAE Fuels \& Lubricants Meeting, SAE Paper 1999-01-1469, Detroit, MI, May 1999. 